\title{
Türkiye'deki Eğitim Sendikalarına Yönelik Bir İnceleme: Amaçlar, Beklentiler ve Sorunlar
}

\author{
Hatice GÜNEŞ KARAMAN*
}

\author{
Çetin ERDOĞAN**
}

Öz

Bu araştırmanın amacı, Türkiye'de faaliyet gösteren eğitim sendikalarının öncelikli amaçları, üyelerin sendikalardan beklentileri ve sendikaların temel sorunlarının belirlenmesidir. Nitel araştırma deseninde yürütülen bu araştırmada veriler yarı yapılandırılmış görüşme yöntemiyle toplanmıştır. Araştırmanın katılımcıları, eğitim iş kolunda faaliyet gösteren ve üye sayısı en fazla olan dört büyük sendikanın (Eğitim - Bir - Sen, Türk Eğitim - Sen, Eğitim - Sen, Eğitim - İş) İstanbul'daki yönetici ve üyelerinden seçilmiştir. Elde edilen veriler içerik analizi tekniğiyle analiz edilmiştir. Araştırma sonuçlarına göre sendikaların eğitim alanındaki öncelikli amaçları, eğitimde temel hakların sağlanması, eğitimin niteliğinin artırılması ve çalışanların haklarının korunmasıdır. Üyelerin sendikalardan beklentileri de benzer şekilde üyelerin haklarının savunulması ve eğitimin niteliğinin artırılmasına katkı sunulmasıdır. Yönetici ve üyelere göre eğitim sendikalarının en önemli sorunları, sendikaların siyasi parti veya görüşlerle ilişkili görülmesi, sendikalara karşı olumsuz algı ve önyargılar ile sendikaların grev hakkının bulunmaması gelmektedir.

Anahtar Kelimeler: Sendikacılık, eğitim sendikacılığı, öğretmen örgütleri.

\section{An Investigation of the Education Unions in Turkey: Goals, Expectations and Problems}

\begin{abstract}
The purpose of the current study is to determine the primary goals of the education unions operating in Turkey, their members' expectations from them and their main problems. In the current study conducted in line with the qualitative research design the data were collected through the semi-structured interview method. The participants of the study were selected from among the directors and the members, living in İstanbul, of the four biggest unions having the highest numbers of members and operating in the field of education. The collected data were analyzed by means of the content analysis technique. The findings of the study revealed that the primary goals of the unions in the field of education are ensuring the basic rights in education, enhancing the quality of education and protecting the rights of the workers. The members' expectations from their unions are the protection of their rights and improving the quality of education. The most important prob-
\end{abstract}

\footnotetext{
* İstanbul Aydın Üniversitesi, Sosyal Bilimler Enstitüsü Yüksek Lisans Öğrencisi, eylul_htc@hotmail.com

${ }^{* *}$ Yrd. Doç. Dr., Yıldız Teknik Üniversitesi, Eğitim Fakültesi, Eğitim Yönetimi Teftişi, Planlaması ve Ekonomisi, cerdogan@yildiz.edu.tr
} 
lems of the unions according to the managers and the members are the political affiliations of the unions, negative perceptions of and prejudices against the unions and lack of the right of going on a strike.

Keywords: Unionism, educational unionism, teacher organizations.

\section{GİRIŞ}

Sosyal bir varlık olan insan, bireysel yaşamında olduğu gibi iş yaşamında da sosyalleşme gereksinimi duymaktadır. Bu gereksinim çerçevesinde insanlar, bir takım mesleki ortak amaçları gerçekleştirmek ve karşılaşılan sorunlara ortak çözümler üretmek amacıyla çeşitli sivil toplum kuruluşları çatısı altında bir araya gelmektedir. $\mathrm{Bu}$ sayede insanlar, bireysellikten öte topluluk olarak seslerini daha çok çıkarmayı, ortak kararlar alıp, amaçlarına ulaşabilmek için örgütlü şekilde hareket ederek daha etkili olmayı amaçlamaktadır. Çalışanların bu türden örgütlenme ihtiyaçlarının doğurduğu en yaygın sivil toplum örgütlerinden biri de sendikalardır.

Dünyada sendikalaşma, fabrikaların kurulması ve sanayileşmenin ilerlemesiyle birlikte ortaya çıkmıştır. Sanayileşme ve bunun ardından işçi sınıfının doğuşu İngiltere' de gerçekleştiği için sendikanın tohumlarının da İngiltere'de atıldığı öne sürülmektedir (İren, 2009, 38). Sanayileşmenin ilk yıllarında fabrikalarda çalışan işçilerin çalışma koşullarının çok ağır, çalışma sürelerinin uzun ve çalışılan fiziksel ortamın da uygunsuz olduğu bilinmektedir (Küçükkalay, 1997, 53). Çalışma koşullarının ağırlığı ve ekonomik zorluklar işçileri yardımlaşmaya ve dernekler kurmaya yöneltmiştir. Ulutaş ve Sönmez'e $(2011,16)$ göre bu örgütlenme hareketleri sendika yapılaşmasının da başlangıcını oluşturmaktadır.

Kelime anlamı olarak sendika, Türk Dil Kurumu Güncel Türkçe Sözlüğü'nde "İşçilerin veya işverenlerin iş, kazanç, toplumsal ve kültürel konular bakımından çıkarlarını korumak ve daha da geliştirmek için aralarında kurdukları birlik" olarak tanımlanmıştır (tdk.gov.tr.).
"Sendika" sözcüğü sanayi devrimiyle Fransa, İtalya, İspanya dışındaki batı ülkelerinde "emek birliği" anlamina gelen, İngilizcede "trade union", Almancada "gewerkschaft" kavramlarıyla adlandırılmış, "şçi” ya da "işveren” sözcükleri getirilerek "işçi/işveren sendikası" oluşturulmuştur (Mahiroğulları, 2011, 2). İşçi sınıfının ortaya çıkmasıyla birlikte gündeme gelen sendikalar daha çok işçilerin, işverenlere ve hükümetlere karşı hak ve çıkarlarını korumak için oluşturulan örgütler olarak nitelenmektedir (Koç, 1998, 2). Sendikalar üyelerine işverene karşı onları temsil etme, eğitme, mesleki gelişim olanakları sağlama, sosyal ekonomik ve özlük haklarını koruma, hukuksal anlamda yardımda bulunma, üyeler arasında dayanışmayı sağlama gibi işlevler sunmaktadır (Kayıkçı (2013, 100). Ortaya çıkışı sanayi devrimine dayanan sendikal faaliyetler, her ülkenin kendi koşullarına bağlı olarak gelişmelerini sürdürmüşlerdir. Özellikle sanayi devrimini tamamlamış ülkelerde sendikaların, toplumsal yaşamda, özellikle demokrasinin yerleşmesinde önemli bir yere sahip olduğu görülmektedir. Bu bağlamda Aldemir (2010, 45) sendikanın demokratik yöntemlerin başarıya ulaşmasında önemli ve etkili bir kurum olduğunu belirtirken; demokrasinin işlemesi ve kendinden bekleneni verebilmesinin sendikaların iyi işlemesine bağlı olduğunu vurgulamıştır.

Çeşitli araştırma bulgularından hareketle Kayıkçı $(2013,101)$ dünyadaki sendikalaşma oranları dikkate alındığında kamu sektöründeki sendikalaşma oranının özel sektöre göre daha yüksek olduğunu; eğitim iş kolunun da en yüksek düzeyde sendikalaşmaya sahip iş kolu olduğunu belirtmiştir. Eğitim sendikaları, eğitime dair ve eğitimcilerin özlük haklarına, 
ekonomik, demokratik sorunlarına çözüm bulması, mağduriyetlerini dile getirmesi bak1mindan önemli örgütlerdir. Gemici'ye göre (2008: 74) öğretmenler, ücretlerinin artması, daha güzel çalışma şartları içinde çalışmalarını sürdürmeleri ve eğitim sorunlarına çözüm bulabilmeleri amacıyla örgütlenmişlerdir. Örgütlenmeler dönem dönem bazen dernek bazen sendika olarak adlandırılmıştır. Ariyawansa (1976, 57), eğitim sendikalarının görevlerini ekonomik ve toplumsal koşulların analizinde, eğitimin ilerlemesinde ve değerlendirilmesinde, toplumun gelişmesinde, toplumsal ve ekonomik ilerlemede temel bir unsur olarak nitelemiştir. Işıklı $(1977,7)$ öğretmenlerin sendikal mücadelesinde örgütlenmeyi güçlendirecek ve mücadeleyi tüm dünyaya yayacak bazı çatı örgütlerin oluştuğunu bu anlamda kurulan ilk öğretmen sendikasının Eğitim Emekçileri Enternasyonali (ITE) olduğunu belirtmiştir. 2. Dünya Savaşı'ndan sonra ise örgütlenmede yeniden yapılanmaya gidilmiş, 1945'te sendikaları bir araya getirmek için Dünya Sendikalar Federasyon'u kurulmuş; 1946'da Uluslararası Öğretmenler Sendika Konferansı Paris'te düzenlenmiş ve bunun ardından da Öğretmen Sendikaları Federasyonu (FISE) kurulmuştur (Demir, 2013, 34).

\subsection{Türkiye'de Öğretmen Örgütlenmesinin Geçmişi}

Sendikal hakların kazanımı ülkelerin siyasi, ekonomik, sosyal özelliklerine göre farklılık gösterebilmektedir. Gündüz'e göre (2010) Osmanlı toplumunda meslek gruplarının örgütlenmesi, dernekler kurup sendikalaşmaları batı toplumlarına göre oldukça geç olmuştur. Yazara göre resmi karakterli, şeffaf çalışma niteliklerine sahip eğitim örgütleri 1908 sonrasında varlık gösterebilmiştir. Türkiye'de öğretmen örgütlenmesinin başlangıcı Akyüz'e (2007) göre Osmanlı döneminde Üniversite ve Darülmuallimîn (Erkek Öğretmen Okulu) mezunlarının 1908'de İstanbul'da kurduğu Encümen-i Muallimîn'e dayanmaktadır. Bunun hemen ardından yine öğretmenlerce Muhafaza-i Hukuk-i Muallimîn Cemiyeti kurulmuş, sonra bu iki örgüt 1908'de Cemiyet-i Muallimîn adı altında birleşmişlerdir. Bundan sonra da Terakki-i Maarif ve İttihad-ı Muallimîn Cemiyeti (1910), Mahfel-i Muallimîn (1911), Milli Talim ve Terbiye Cemiyeti (1916) ve Muallimler Cemiyeti (1918) gibi adlar altında çeşitli öğretmen örgütleri kurulmuştur (Akyüz, 2007). Genellikle meslek mensupları tarafindan kurulan bu örgütlerin temel amacı, toplumun eğitimsizlik sorununun çözümüne katkı sunmak, bunun yanında da meslek mensubiyeti, yardımlaşma ve dayanışma bağları oluşturmak, sosyal faaliyetler yaparak geleneği korumak ve yeniliklere açık olmaktır (Gündüz, 2010). 1920'de Atatürk'ün desteği ile öğretmenlerin sosyal ve ekonomik durumlarını düzeltmek, geliştirmek ve Milli Mücadele'ye destek vermek amacıyla Türkiye Muallimler ve Muallimeler Derneği faaliyete geçirilmiş daha sonra bu dernek Türkiye Muallimler Birliği adını almış ve 1929'da Türkiye'de 240 şubeye ulaşarak başarılı bir örgütlenme sergilemiştir (Eraslan, 2012). Ancak sonrasında ülkede yaşanan olayların etkisi ile gücünü yitirmiş, üye kaybı yaşamış ve nihayetinde 1935- 1936 öğretim yılında kapatılmıştır (Altunya, 1998, 41).

Cumhuriyet döneminde ise 1938 tarih ve 3512 sayılı Cemiyetler Kanunu'ndaki "Sınıf esasına dayalı cemiyet kurulamaz." ifadesinin 1946'da yapılan değişiklikle metinden çıkarılması ile sendikacılık faaliyeti yasallık kazanmıştır (Mahiroğulları, 2001). Sendikaları yasal zemine oturtan asıl önemli düzenleme ise $1947^{\prime}$ de çıkarılan 5018 sayılı İşçi ve İşveren Sendikaları ve Sendika Birlikleri Hakkında Kanun ile yapılmıştır (Resmi Gazete, 6542). Bu kanun sendikayı "Aynı iş kolunda veya bu iş kolu ile ilgili işlerde çalışanların yardımlaşmaları ve ortak menfaatlerini korumaları ve temsil etme- 
leri amaçlarıyla kendi aralarında kurabilecekleri dernekler işçi sendikalarıdır" şeklinde tanımlamıştır (Md.1). Aynı kanun işveren sendikalarını da "işverenlerin aynı maksatla kendi aralarında kurabilecekleri dernekler" olarak tanımlamıştır (Md. 1). 1963'te çıkarılan 274 sayılı Sendikalar Kanunu ile işçilere ilk defa grevli toplu pazarlık hakkı veren 275 sayılı Toplu İş sözleşmesi Grev ve Lokavt Kanunu sendikac1lığın yasal zemininde köklü değişiklikler ve önemli kazanımlar getirmiştir (Mahiroğulları, 2001). Bu yasal zeminin sendikalaşmanın önünü açtığı söylenebilir.

$\mathrm{Bu}$ dönemde örgütlenme ve sendikalaşma hareketlerinin arttığı gözlenmektedir. Daha önce Ankara Öğretmenler Yardımlaşma Derneği adıyla kurulan dernek 1948'de alınan bir kararla Öğretmen Yardımlaşma Dernekleri Birliği adını almış, sonrasında ise 1954'te Türkiye Öğretmen Dernekleri Milli Federasyonu'na (TÖDMF) dönüşmüştür. Bu örgütlenme hareketlerini 1965'te kurulan Türkiye Öğretmenler Sendikası (TÖS), Türkiye İlkokul Öğretmenleri Sendikası (İLK-SEN) ve Türkiye İlkokul Öğretmenleri Federasyonu izlemiştir (Güvenç, 2008). 1965'te kurulan bir diğer sendika ise Milliyetçi Öğretmenler Dernekleri ve Birliklerinin birleşmesiyle meydana gelen Milliyetçi Türk Öğretmenleri Sendikası'dır (Eraslan, 2012). Eğitim alanındaki bu sendikal faaliyetler 1971 askeri müdahalesiyle son bulmuş ve sendikalar kapatılmıştır (Eraslan, 2012). Koç'a (2012, 6) göre, 12 Mart 1971 muhtırasından sonra anayasada değişiklik yapılarak kamu personeline sadece mesleki birlik kurma hakkı verilmiştir. Böylece 1965- 1971 yılları arasında var olan eğitim sendikacılığı tekrar dernekleşme sürecine girmiştir. Aynı kısıtlayıcı hareket dernekleşen öğretmen örgütleri için 1980'de de tekrarlanmıştır. Çalışanlara sağlanan siyasal hakların siyasal işçi hareketlerinde kötüye kullanıldığından hareketle 1980 askeri müdahalesinden sonra çıkarılan 2821 sayılı Sendikalar Kanunu ve 2822 sayılı Toplu İş Sözleşmesi Grev ve Lokavt Kanunu ile işçilerin sendikal haklarına sınırlamalar getirilmiştir (Mahiroğullar1, 2001).

1980 askeri müdahalesinden sonra ilk öğretmen örgütü, EĞİT-DER adı altında 1987'de kurulmuştur. 1982 Anayasasında sendikacılığı yasaklayan bir hüküm bulunmaması nedeniyle bu dernek sendikalaşma isteklerini dile getirmiştir. EĞİT-DER bünyesinden bazı öğretmenlerin girişimiyle 1990'da EĞİTiM-İŞ ve EĞİTSEN sendikaları kurulmuş, sonrasında bu iki sendika 1995'te EĞİTIM-SEN adı altında birleşmiştir (Erdem, 2013). Yine aynı dönemde diğer sendikalardan Eğitim Bir-Sen ile Türk Eğitim-Sen de 1992'de Ankara merkezli olarak kurulmuştur (Cerev, 2013).

\subsection{Türkiye'de Öğretmen Örgütlenmesinde Mevcut Durum}

Çalışanların sendikal hakları bakımından mevcut durumda 1982 Anayasasında en son 2010 'da yapılan değişikliklerle birlikte çalışanlar ve işverenler sendika kurma hakkına (Md. 51), işçiler ile memurlar ve diğer kamu çalışanları toplu iş sözleşmesi hakkına (Md. 53), yalnız işçiler ise grev hakkına sahiptir (Md. 54). Bugün Türkiye'deki eğitim sendikaları arasında en çok üye sayısına sahip dört sendika sırasıyla Eğitim-Bir-Sen, Türk Eğitim-Sen, Eğitim-Sen ve 2005'te kurulan Eğitim-İş sendikalarıdır. Çalışma ve Sosyal Güvenlik Bakanlığı'nın Temmuz 2015 istatistiklerine göre Türkiye'de eğitim, öğretim ve bilim hizmetleri iş kolundaki sendikalar ve sendikalaşma oranlarına ilişkin 2004 ve 2015 yıllarına ait sayısal veriler Tablo 1 'de verilmiştir. 
Tablo 1. Türkiye' de eğitim, öğretim ve bilim hizmetleri iş kolundaki sendikalara ait veriler

\begin{tabular}{lcccccc}
\hline & \multicolumn{2}{c}{ Üye Sayısı } & \multicolumn{2}{c}{ Sendikalaşma Oranı (\%) } & \multicolumn{2}{c}{ Sendikalılar İçindeki Payı } \\
\cline { 2 - 7 } Sendika & 2004 & 2015 & 2004 & 2015 & 2004 & 2015 \\
\hline Eğitim-Bir-Sen & 48.517 & 340.365 & 6,59 & 30,51 & 14,27 & 43,96 \\
Türk Eğitim-Sen & 135.224 & 220.041 & 18,38 & 19,72 & 39,77 & 28,42 \\
Eğitim-Sen & 154.524 & 127.214 & 21,00 & 11,40 & 45,45 & 16,43 \\
Eğitim-İş & - & 45.157 & - & 4,05 & - & 5,83 \\
Dört Sendika İçin Toplam & 338.265 & 732.777 & 45,97 & 65,68 & 99,49 & 94,65 \\
Diğer Sendikalar & 1.743 & 41.444 & 0,24 & 3,71 & 0,51 & 5,35 \\
Toplam Sendikalı Sayısı & 340.008 & 774.221 & 46,21 & 69,39 & 100,0 & 100,0 \\
Toplam Kamu Çalışanı Sy. & 735.745 & 1.115 .703 & & ---- & & --- \\
\hline
\end{tabular}

Kaynak: Çalışma ve Sosyal Güvenlik Bakanlığ̣ 2004 ve 2015 İstatistiklerinden derlenmiştir.

Tablo 1'den de görüldüğü gibi Türkiye'deki toplam 1.115.703 kamu çalışanının \%69,39'u sendikalaşmıştır. 2004'te sendikalaşma oranının \%46,21'de olduğu dikkate alındığında son 11 yılda eğitim iş kolunda sendikalaşmada ciddi bir yükseliş gerçekleştiği görülmektedir. En dikkat çekici gelişme, en çok üye sayısına sahip sendikanın 2004'te Eğitim-Sen iken 2015'te Eğitim Bir-Sen olmasıdır. Eğitim BirSen $2004^{\prime}$ te 48 bin olan üye sayısını büyük bir artış kaydederek 2015 'te 340 bine yükseltmiştir. Sendikalı çalışanların $2004^{\prime}$ te $\% 99,49^{\prime}$ u en büyük üç sendikaya üye iken 2015'te bu oran \%88,82'ye düşmüştür. Bu düşüşte 2005'te kurulan ve 45 binin üzerinde üye sayısına ulaşan Eğitim-İş sendikası en önemli etkendir. Diğer dikkat çeken ayrıntı ise tüm sendikalar üye sayısını artırırken Eğitim-Sen'in üye kaybetmiş ve en yüksek üyeye sahip sendika ünvanını kaybedip üçüncülüğe gerilemiş olmasıdır. Ayrıca "Eğitim, Öğretim ve Bilim Hizmetleri" sınıfındaki sendika sayısı 2004'te altı iken 2015'te bu sayı 34'e yükselmiştir (ÇSGB, 2015).

Türkiye' de eğitim sendikalarının faaliyetleri ve işleyişi çeşitli araştırmalara konu edilmiştir. Bu konuda son yıllarda yapılan çalışmalar incelendiğinde öğretmen örgütlenmelerinin tarihsel süreci (Akyüz, 2007, Gündüz, 2010; Eraslan, 2012; Cerev, 2013); yapısı ve örgütlenmesi (Karagöz, 2010; Arlı, 2011) eğitimcilerin sendikala- ra ilişkin görüşlerinin (Gül, 2007; Çınar, 2008; Demiryürek, 2008; Demir, 2013; Erdem, 2013; Kayıkçı, 2013, Koç, 2013, Taşdan, 2013) ağırlıklı olarak konu edildiği görülmektedir.

Bu çalışmanın amacı, Türkiye'de faaliyet gösteren eğitim sendikalarının öncelikli amaçları, üyelerin sendikalardan beklentileri ve sendikaların temel sorunlarına ilişkin, sendika yöneticilerinin, sendikaya üye öğretmen ve okul yöneticilerinin görüşlerinin belirlenmesidir. $\mathrm{Bu}$ genel amaç kapsamında aşağıdaki sorulara yanıt aranmıştır:

- Eğitim sendikalarının eğitimdeki öncelikli amaçları nelerdir?

- Sendika üyelerinin sendikalardan beklentileri ve üye olma gerekçeleri nelerdir?

- Sendika yöneticileri ve üyelerine göre eğitim alanında sendikacılıkta görülen en önemli sorunlar nelerdir?

Sendikaların temel faaliyetleri ile işleyişine yönelik sorunların bilimsel bir çalışma ile ortaya konulmasının, Türkiye'de eğitim iş kolundaki sendikacılığın gelişimine katkıda bulunacağ1 umulmaktadır. Özellikle hem sendika yöneticilerinin hem de öğretmen ve okul yöneticiliği yapan üyelerinin görüşlerini aynı anda yansıtması, sendikaların öncelikli amaçlarını, üyelerin beklentilerini ve sendikal sorunları 
aynı çalışma içerisinde ortaya koyması bu çalışmanın özgün yönünü oluşturmaktadır.

\section{YÖNTEM}

\subsection{Araştırmanın Modeli}

Nitel araştırma deseninde yürütülen bu araştırmada veriler yüz yüze görüşme yöntemiyle toplanmıştır. Yarı yapılandırılmış görüşme tekniğiyle sendika yöneticilerinin ve üyelerinin sendikaların öncelikli amaçları, üyelerin beklentileri ve eğitim sendikalarının sorunlarına yönelik görüşleri belirlenmeye çalışılmıştır.

\section{2 Çalışma Grubu}

Araştırmanın çalışma grubuna üye sayısı en fazla olan dört büyük sendikadan (Eğitim-BirSen, Türk Eğitim-Sen, Eğitim-Sen, Eğitim-İş) toplamda 12 sendika üyesi ve 12 sendika yöneticisi dahil edilmiştir. Çalışma grubunun belirlenmesinde amaçlı örnekleme ve maksimum çeşitlilik yaklaşımları kullanılmıştır. Maksimum çeşitlilik yaklaşımında çalışılan probleme taraf olabilecek bireylerin çeşitliliğini maksimum derecede yansitmak ve bu sayede problemin farklı boyutlarını ortaya koymak amaçlanmaktadır (Yıldırım ve Şimşek, 2013).

Çalışma grubu İstanbul ilindeki sendikalar ile bu sendikalara üye olup resmi ilkokul, ortaokul ve liselerde görev yapan eğitimcilerden oluşmaktadır. Farklı görüşlerin ve değişik bakış açılarının araştırma bulgularına yansıtılabilmesi amacıyla görüşme yapılan üyeler öğretmen (4), müdür yardımcısı (4) ve müdür (4) olarak görev yapanlardan; sendika yöneticileri ise şube başkanı (4), ilçe başkanı (3), ilçe başkan yardımcısı (2) ve sekreter (3) olarak görev yapanlardan seçilmiştir. Sendika yöneticilerinden 11'i erkek, biri kadındır ve yaşları 28 ile 53 arasında değişmektedir. Hemen her branştan eğitimcilerden oluşan sendika yöneticilerinin büyük çoğunluğu 7 ile 26 yıl arası, sadece biri ise 2 yıldır mevcut sendikalarına üye bulunmaktadır. Sendika üyelerinin ise $10^{\prime} \mathrm{u}$ erkek, ikisi kadındır ve yaşları ise 35-57 arasında; mevcut sendikalarına üyelik süreleri ise 4 ile 25 yıl arasında değişmektedir.

\subsection{Verilerin Toplanması}

Araştırmanın verileri görüşme yöntemi ile toplanmıştır. Görüşmeler için araştırmacılar tarafından geliştirilen ve açık uçlu sorulardan oluşan yarı yapılandırılmış görüşme formu kullanılmıştır. Hazırlanan görüşme formu taslağ1 uzman görüşüne sunulmuş, uzman görüşleri doğrultusunda forma son şekli verilmiştir. Görüşülen katılımcılardan izin alınarak ses kaydı yapılmış, sonrasında ses kayıtları araştırmacılar tarafından çözümlenmiştir. Ses kaydına izin vermeyen katılımcıların görüşleri not alınmıştır. Görüşmeler ortalama 30 dakika sürmüştür.

\subsection{Verilerin Analizi}

Araştırma kapsamında toplanan veriler içerik analizi tekniğiyle analiz edilmiştir. Yıldırım ve Şimşek'e göre (2013) içerik analizinde toplanan veriler önce kavramlaştırılır, daha sonra kavramlara göre mantıklı bir biçimde düzenlenir ve buna göre veriyi açıklayan temalar oluşturulur. Verilerin analizinde öncelikle katılımcılara birer kod verilmiştir. Sendika yöneticileri için Eğitim Bir Sen (EBY1,2,3), Eğitim-Sen (ESY1,2,3), Türk Eğitim Sen (TESY1,2,3), Eğitim-İş (EİY1,2,3); sendika üyeleri için Eğitim Bir Sen (EBÜ1,2,3), Eğitim-Sen (ESÜ1,2,3), Türk Eğitim Sen (TESÜ1,2,3), Eğitim-İş (EİÜ1,2,3) şeklinde kodlar kullanılmıştır. Görüşler önce kavramlaştırılmış, sonrasında ise ortak temalar üretilmiş ve görüşler bu temalar çerçevesinde sunulmuş ve yorumlanmıştır.

Görüşme yöntemiyle yürütülen nitel araştırmalarda katılımcıların görüşlerinden doğrudan alıntılara yer vermenin ve katılımcıların çeşitliliğini artırarak olabildiğince farklı görüşleri 
ortaya koymanın geçerliği; araştırmanın süreçlerine ve katılımcı özelliklerine ilişkin ayrıntılı bilgi sunmanın da güvenirliği güçlendirdiği belirtilmektedir (Yıldırım ve Şimşek, 2013). Bu doğrultuda geçerlik kapsamında, araştırma bulguları yorumlanırken katılımcıların doğrudan alıntılarına yer verilmiş, araştırmanın katılımcılarının özellikleri ve araştırma süreçleri hakkında ayrıntılı bilgi sunulmuştur.

\section{BULGULAR}

Araştırmanın katılımcılarının görüşleri üç ana başlıkta analiz edilmiş ve bulgular raporlaştırilmıştır.

\subsection{Sendikaların Eğitim Alanındaki Öncelik-} leri

Katılımcılardan sendika yöneticilerine öncelikle eğitim alanındaki önceliklerinin ne olduğu sorulmuş ve elde edilen veriler Tablo 2'de özetlenmiştir.

Tablo 2. Sendikaların eğitime bakışına ilişkin sendika yöneticilerinin görüşleri

\begin{tabular}{|c|c|}
\hline TEMA & GÖRÜŞLER \\
\hline \multirow{5}{*}{ Temel haklar $(\mathrm{f}=14)$} & - $\quad$ Parasız eğitim olmalı (ESY1, EIY2, EIYY3, ESY2, ESY3) \\
\hline & - $\quad$ Demokratik, çağdaş, nitelikli eğitim (ESY1, EBY1, EİY1, EİY2, ESY2) \\
\hline & - $\quad$ Devlet maddi olanakları artırmalı (ESY3, TESY2) \\
\hline & - $\quad$ Ana dilde eğitim olmalı (ESY1) \\
\hline & - $\quad$ Sosyal adalet ve fırsat eşitliği gerçekleşmeli (TESY3) \\
\hline \multirow{8}{*}{ Eğitimin niteliği $(\mathfrak{f}=10)$} & - $\quad$ Atatürk ilke ve ink1laplarına bağlı bir eğitim (TESY3, TESY2, EİY3) \\
\hline & - $\quad$ Müfredat değişmemeli ve sabit kalmalı (EBY1, TESY1) \\
\hline & - $\quad$ Toplumun beklentisi doğrultusunda eğitim (EBY1) \\
\hline & - $\quad$ Gelişen teknolojinin kullanıldığı bir eğitim (TESY3) \\
\hline & - $\quad$ Sosyal ve kültürel alanda eğitim sağlanmalı (EBY3) \\
\hline & - $\quad$ Ulusal değerleri korumalı (EIYY1) \\
\hline & - $\quad$ Okulların fiziksel altyapı sorunları çözülmeli (TESY1) \\
\hline & - $\quad$ Öğrencilerde madde bağımlılığ 1 ile mücadele (TESY1) \\
\hline \multirow{5}{*}{$\begin{array}{l}\text { Çalışanların } \\
(\mathrm{f}=7)\end{array}$} & - $\quad$ Sosyal ve özlük hakları düzeltilmeli (EBY2, EBY3, EIY3) \\
\hline & - $\quad$ Öğretmen maaşlerı ve ekonomik koşulları iyileşmeli (TESY1, TESY2) \\
\hline & - $\quad$ Üyelerin menfaatleri korunmalı (TESY3) \\
\hline & - $\quad$ Çalışanlar ve öğrenciler kılık kıyafetlerinde özgürce hareket etmeli \\
\hline & $(\mathrm{EBY} 1)$ \\
\hline
\end{tabular}

Tablo 2'de görüldüğü gibi sendika yöneticilerinin görüşleri "temel haklar", "eğitimin niteliği" ve "çalışanların hakları" adı altında üç temada toplanmıştır.

Temel haklar: Sendika yöneticileri, eğitim finansmanının vatandaşın cebinden finanse edilmeden, kamusal hizmet mantığıyla ücretsiz sunulması gerektiğini belirtmiştir. TESY1 kodlu yönetici bu görüşünü, “Türk eğitim sisteminin başlıca sorunu çekilen kaynak sıkıntısıdır. Yani eğitime gereken pay ayrulmıyor." şeklinde dile getirmiştir. Ayrıca yasalarla belirlenen demokratik, çağdaş ve nitelikli eğitim hizmetinin sunulmasına vurgu yapılmıştır. Bir yönetici (EIY1), "Ülkemizin milli demokratik devrimin demokratikleşmenin medeni çizgide yol alması şeklinde durum olunca eğitimin bu çizgide devam etmesi gerektiŏini savunuyoruz." sözleriyle bu 
görüşünü ifade etmiştir. Bunun yanında sendika yöneticileri devletin eğitime daha çok maddi katkı sunması, eğitimde sosyal adelet ve fırsat eşitliğinin sağlanması ve ana dilde eğitim hakkının eğitimdeki öncelikleri olduğunu belirtmiştir.

Eğitimin niteliği: Katılımcılar önceliklerinin; Atatürk ilke ve inkılaplarına bağlı, toplumsal beklentiler doğrultusunda, gelişen teknolojiyi kullanan, ulusal değerleri koruyan nitelikte bir eğitimin öncelikli olması gerektiğini belirtmişlerdir. Bunun yanında bazı yöneticiler eğitimin niteliğine zarar veren müfredatın sık değişmesi, okulların fiziksel alt yapı sorunları ve öğrencilerde madde bağımlılığı sorunlarının giderilmesini temel öncelik olarak görmüşlerdir. Bu konuda bir yönetici (TESY1) “Okullarm fiziki altyapı şartlarında büyük eksiklikler var bunların giderilmesi gerekir, aynı zamanda okulları son zamanlarda abluka altına alan uyuşturucu proble- minin giderilmesi gerekir." görüşünü dile getirmiştir.

Çalışanların hakları: Bazı katılımcılara göre sendikaların eğitimdeki öncelikleri eğitimcilerin sosyal güvencelerinin artırılması, özlük haklarının ve ekonomik olanaklarının iyileştirilmesi olmalıdır. Bu konuyla ilgili EBY3 sendikasına mensup katılımc1: "Türkiye'de eğitimin; milli ve sürekli gelişen şekilde kalitesini artırmak istiyorsak öğretmenin sosyal, ekonomik koşullarını iyileştirerek bu noktaya gelebiliriz." görüşünü belirtmiştir. Ayrıca öğretmenlerin çıkarlarının korunması ve kılık kıyafet serbestliğinin sağlanması da öncelikler listesinde yer almıştır.

\subsection{Sendika Üyelerinin Sendikalardan Bek- lentileri ve Üye Olma Gerekçeleri}

Sendika üyelerine sendikalara neden üye oldukları, yani sendikalarden ne gibi beklentilere sahip oldukları sorulmuştur. Üyelerin verdiği cevaplar Tablo 3'te sunulmuştur.

Tablo 3. Sendika üyelerinin sendikalardan beklentileri ve üye olma gerekçeleri

\begin{tabular}{|c|c|}
\hline TEMA & GÖRÜŞLER \\
\hline $\begin{array}{l}\text { Üyelerin } \\
\text { Haklarını Savunma } \\
(\mathrm{f}=16)\end{array}$ & 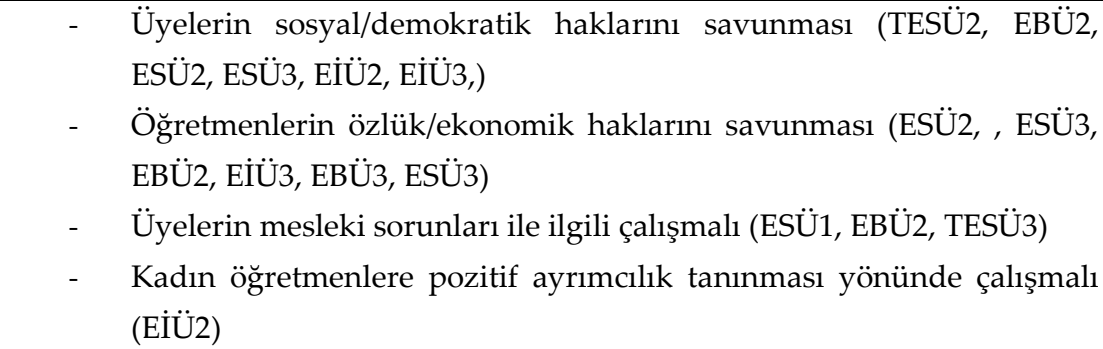 \\
\hline $\begin{array}{l}\text { Eğitime Katkı } \\
(\mathrm{f}=13)\end{array}$ & $\begin{array}{ll}\text { - } & \text { Eğitimin niteliğini artırmaya yönelik çalışmalar (EBÜ1, ESÜ1, Eİ̈̈2) } \\
\text { - } & \text { Eğitim politikalarının yenilemesine yönelik çalışmalar (TESÜ2) } \\
\text { - } & \text { Eğitim sorunlarının çözümüne yönelik çalışmalar (ESÜ2, EBÜ3, TE- } \\
\text { SÜ3) } & \text { Okulların fiziki şartlarını düzeltilmesine yönelik çalışmalar (EÏÜ1, } \\
\text { - } & \text { TESÜ1) } \\
\text { - Öğrenci haklarının korunması (ESÜ1, EİÜ1, EBÜ2) } \\
\text { - Öğrencilerde fırsat ve olanak eşitliğinin sağlanmasına yönelik çalış- } \\
\text { malar (TESÜ1) }\end{array}$ \\
\hline $\begin{array}{l}\text { Sendikal Faaliyet } \\
(\mathrm{f}=2)\end{array}$ & $\begin{array}{ll}\text { - } & \text { Diğer sendikalarla ilişki ve işbirliği kurması (ESÜ2) } \\
\text { - } & \text { Üyeleri sendikal mücadelede bilinçlendirmesi (Eİ̈̈1) }\end{array}$ \\
\hline
\end{tabular}


Tablo 3'te görüldüğü gibi üyelerin sendikalardan beklentilerine ilişkin görüşleri "üyelerin haklarını savunma", "eğitime katkı" ve "sendikal faaliyet" adı altında üç temada toplanmıştir.

Üyelerin haklarını savunma: Üyelerin sendikalardan en önemli beklentileri, üyelerin sosyal ve demokratik haklarının savunulması, ekonomik veya özlük haklarının kazanılmasına yönelik çalışmalar yapılması, üyelerin mesleki sorunlarıyla ilgilenilmesidir. TESÜ3 kodlu üye sendikasından beklentisini "Ĕ̆gitim sendikalartnın içeriği eğitim olduğu için önceliği de eğitim ve öğretim çalışanların problemlerini asgariye indirmek olmalıdır." şeklinde; ESÜ2 kodlu üye ise "Ĕ̆gitim sendikalarının çalışanların ekonomik, demokratik ve özlük haklarına yönelik mücadele vermeleri gerekiyor. Edindikleri haklar korumak için de demokratik mücadelenin sendikal mücadelede yer tutması gerekiyor." sözleriyle dile demiştir. Bunun yanında bir üye kadın öğretmenlere pozitif ayrımcılık sağlanması için gayret gösterilmesi beklentisini dile getirmiştir.

Eğitime katkı: Üyelere göre sendikalar eğitim kalitesini artırmalı, eğitimin içeriğini düzeltmeli, eğitim politikasının yenilenmesine, eğitim sorunlarının çözümüne ve okulların fiziki şartlarının iyileşmesine katkı sunmalıdır. Ayrıca öğrenci hakları ile fırsat ve olanak eşitliğine yönelik çalışmalarda bulunmalıdır. Katılımc1lardan bazıları bu yöndeki görüşlerini "Sendika- ların öncelikleri eğitim olmalıdır, yani eğitim kalitesini arttırmak, eğitimi geliştirmek, eğitim koşullarını geliştirmektir (EBÜ1)."; "Ĕ̆̈itim sendikaları öncelikle eğitimle ilgilenmelidir, eğitimin içeriği, kalitesi, müfredatı, her şeyiyle ilgilenmelidir (ESÜ1)."; "Eğitim sendikalarının önceliği eğitim politikalarmın şekillenmesinde etkin rol oynamak olmalıdır (TESÜ2)." sözleriyle dile getirmişlerdir. Öğrenci haklarının savunulması yönündeki beklentisini EIÜ2 kodlu üye " $4+4+4$ sistemiyle birlikte hem ögrrenci hem öğretmenler mağdur olmuşlardır. Öğrenciler istemedikleri eğitim sistemiyle karşı karşıya kalmışlardır. Sendikaların önceliği bu sorunları çözmek olmalıdır." şeklinde ifade etmiştir.

Sendikal Faaliyet: Bazı üyelerin sendikalardan beklentisi ise diğer sendikalarla işbirliği ve ilişki kurması ve bunun yanında üyelerini sendikal mücadelede bilinçlendirmesidir. Eİ̈̈1 kodlu üye "Sendikaya üye yapmak yeterli değil, sendikaların diğer görevi de üye yaptıkları kişileri sendikal faaliyetlere yönelik bilinçlendirmek olmaladır. Bu öneri Türkiye'deki sendikal mücadelenin önünü açacaktır." görüşünü ileri sürmüştür.

\subsection{Sendika Yönetici ve Üyelerinin Bakış Açısıyla Eğitim Sendikalarının Sorunları}

Araştırmaya katılan sendika yönetici ve üyelerine Türkiye'de eğitim sendikalarıyla ilgili gördükleri en önemli sorunlar sorulmuş ve alınan cevaplar Tablo 4'te sunulmuştur.

Tablo 4. Yönetici ve üyelere göre eğitim alanında sendikalarla ilgili en önemli sorunlar

TEMA GÖRÜŞLER

- Sendikanın belli bir siyasi ideolojinin temsilcisi olması (EBY1, EBY2, EBY3, TESY1, TESY2, TESY3, ESY1, ESY3, EIY1, EIY2,

Sendika - Siyaset İlişkisi $(\mathrm{f}=22)$ EBÜ1, ESÜ1, EBÜ3, TESÜ3, TESÜ1, EIÜ1, ESÜ3)

- Sendika - siyaset ilişkisi nedeniyle üye azlığı (EBY1, TESY2, ESY1, EIY2)

- Dönemsel ideolojik baskıların olması (ESY2) 


\begin{tabular}{|c|c|}
\hline $\begin{array}{l}\text { Sendikacılığa } \\
\text { Bakış } \\
(\mathrm{f}=21)\end{array}$ & $\begin{array}{ll}\text { - } & \text { Toplumda sendikacılık bilincinin zayıflı̆̆ı (EBY1, TESY2, TESY3, } \\
\text { EIY2, EIY3, Eİ̈2) } \\
\text { - } \\
\text { Sendikaların siyasi kimliğinden kaynaklı olumsuz bakış (TESY2, } \\
\text { EIYY2, EBY3, EBY1, ESÜ1, EBÜ2) } \\
\text { - } \quad \text { Üyelerin örgütlü yapıya/sendikacıllı̆g güvenmemeleri (ESY1, } \\
\text { EIYY2, ESY3, TESY3) } \\
\text { - } \\
\text { - Sendikacılığa karşı önyargılı olunması (TESY2, EBY3, EBY2) } \\
\text { Sendika üyeliğinden dolayı kariyerinin zarar görmesi endişesi } \\
\text { (EIY2, ESY2) } \\
\text { - Genç eğitimcilerin apolitik olması (EIY3) }\end{array}$ \\
\hline $\begin{array}{l}\text { Yapisal/Yasal Sorunlar } \\
(\mathrm{f}=19)\end{array}$ & $\begin{array}{ll}\text { - } & \text { Sendikaların bölünmüş ve çok sayıda olması (EIYY3, ESY1, EBY3, } \\
\text { ESÜ1, TESÜ1, ESÜ2, Eİ̈̈1, Eİ̈2, EBÜ1, EBÜ2, EBÜ3) } \\
\text { - } \quad \text { Yasaların sendikalara yeterince hak tanımamış olması (ESY1, } \\
\text { EİY1, ESY2, Eİ̈1, Eİ̈2, ESÜ2). } \\
\text { - } \quad \text { Uzlaştırma komisyonunun lehine bir şey olmaması (EIY1) } \\
\text { - } \quad \text { Sendikaların yeterli gelirinin olmaması (EIY3) }\end{array}$ \\
\hline $\begin{array}{l}\text { İşleyiş Sorunları } \\
(\mathrm{f}=16)\end{array}$ & $\begin{array}{ll}\text { - } & \text { Memur sendikacılığının yeni olması (EIY1, EBY2, EIY2) } \\
\text { - } & \text { Sendikaya öğretmenler dişındaki çalışanların üye olmamas1 } \\
& \text { (EIY3, ESY2) } \\
\text { - } & \text { Toplumun ve çalışanların sorunlarına çözüm üretememesi (EIY1, } \\
& \text { ESY3, EBÜ3, ESÜ3) } \\
\text { - } & \text { Özeleştiri mekanizmasının olmaması (ESY2, EBÜ1, ESÜ1, EÏÜ1, } \\
& \text { EBÜ3) } \\
\text { - } & \text { Sendikaların proje üretememesi (TESÜ2) } \\
\text { - } & \text { Kadınların sendika yönetiminde ön planda olmaması (EBÜ3) }\end{array}$ \\
\hline
\end{tabular}

Tablo 4'te görüldüğü gibi, sendika yöneticilerinin ve üyelerinin eğitim alanında sendikacılıkla ilgili gördükleri sorunlar "sendikacıllğa olumsuz bakış", "sendika - siyaset ilişkisi", "yapısal/yasal sorunlar" ve "işleyiş sorunları" temaları altında toplanmıştır. Bu konuda dikkat çekici olan, yönetici ve üyelerin görüşlerinin birbiriyle örtüşmesi ve aynı paralelde sorunların dile getirilmesidir.

Sendikaya olumsuz bakış: Toplumdaki sendika algısının olumsuzluğu katılımciların belirttiği sorunların başında gelmektedir. Henüz toplumda sendikacılık bilincinin gelişmemiş olması, çalışanların sendikacılığa güvenmeme veya inanmamaları, sendika üyeliğinin bir siyasi kimlik olarak algılanması nedeniyle çalışanlardaki fişlenme korkusu, sendika üyeliğinin kariyerde yükselmeyi engellemesi endişesi ve yönetimden çekinme gibi sorunlar bu olumsuz algı ile ilişkili sorunlar olarak görülmektedir. Bazı katılımcılar bu konudaki görüşlerini “Öğretmenler sendika konusunda bilinçli değil. Sendikalar kalıplara sokuluyor ve ne işe yaradiğı ile ilgili bir bilinç oluşmuyor (TESY2)."; "Ĕ̆gitimciler etiketlenme korkusu ile sendikaya üye olmuyorlar (ESY2)."; "Hükümete yakm sendikanın güç kazanması insanlarn diğer sendikalara üye olmaların engelliyor (ESY1)."; "Çalışanlarda 'Tayin olmak için şu sendikaya üye olacaksın' algısı var. Bu nedenle sendikalara zoraki üye olunuyor ve bu olumsuz bir durum (ESÜ1)." ve "Üye yaparken kişi belli kaliba sokuluyor, 'buna üye olursan şucu- 
sun' şeklinde insanlar kategorize ediliyor (EBÜ2)." sözleriyle dile getirmişlerdir.

Sendika-siyaset ilişkisi: Sendika yöneticileri ve üyelerinin tamamına yakını eğitim sendikalarının belirli siyasi görüşlerle ilişkili olmasını sendikalarının en önemli sorunlarından biri olarak görmüşlerdir. Birçok katılımcı sendikaları siyasi partilerin uzantısı gibi hareket etmeleri yönüyle eleştirmiştir. Bazı sendika yöneticileri bu yöndeki eleştirilerini "Partilerle sendikalar aynı sosyolojik tabandan beslendikleri için o tabanın beklentilerine uymak durumundalar. Bu kalıpların dışına çıkamıyorlar. Bu da sendikacılı̆̆ın layıkıyla yapılmasını engelliyor (EBY1)."; "Sendikalar devlet siyasetinden bağımsız değil (ESY1)." ve "Partilerle memur sendikaları ilişkilendiriliyor, bunun düzeltilmesi gerekiyor (EIY1)." sözleriyle dile getirmiştir. Bir katılımcı (ESY2) ise dönemsel olarak sendikalara ideolojik temelli baskıların yapıldığını belirtmiştir. Üyeler de aynı paraleldeki görüşlerini "Şu anda dört büyük eğitim sendikası var, hepsi de siyasetin bir koluyla ilgili (EBய̈1)." ve "Türkiye'de sendikalarm siyasi yapı içerisinde yer alması sendikal örgütlenmeye ciddi zarar veriyor (Eİ̈̈1)." sözleriyle ifade etmişlerdir.

Yapısal/yasal sorunlar: Bu konuda eğitim iş kolundaki sendikaların sayısının çokluğu örgütlü kitleyi böldüğü ve gücün zayıflattığ1 gerekçesiyle bir sorun olarak görülmektedir. Bu durum sendikaların yeterince işbirliği yapamaması nedeniyle eleştirilmektedir. Eğitim sendikalarına yasaların yeterince hak tanımamış olması bu bağlamda eğitim sendikalarının toplu sözleşme hakkına sahip iken grev hakk1nın bulunmaması diğer bir önemli sorundur. Ayrıca yasaların toplu sözleşmelerde uzlaştırma komisyonunun lehine ciddi bir hak tan1mamış olması ve sendikaların ekonomik gelirlerinin az olması da katılımcılarca sorun olarak ifade edilmiştir. Katılımcılardan bazı yöneticiler bu konudaki görüşlerini “Bu kadar bölünmüş bir sendikaculikta ne derece faydal olunur bilmiyorum. Bütün eğitimcilerin tek bir çatı altında toplanması gerekir (EBY2)." ve "Çă̆daş ülkelerde sendikanın grev yapmak gibi bir silahı vardır; ancak bizde böyle bir şey söz konusu değil. Bu da kararların alınmasında büyük bir sıkıntı teşkil etmektedir (EIYY2)." sözleriyle dile getirmişlerdir. Üyeler de benzer sorunları "Biz çok bölündü̆̆̈̈müz zaman işveren noktasında hükümet, bölünmüşlüğ̈̈ kullanıyor. Ortak güç oluşturamıyoruz (EBய̈2)." ve "Toplu sözleşme tek başına yeterli değil, yaptırım gücü olmayacağı için grev hakkı da olmalı (EİÜ1)." sözleriyle belirtmişlerdir.

İşleyiş sorunları: Katılımcılara göre genelde memur sendikacılığının, özelde ise eğitim sendikacılığının diğer ülkelere kıyasla yeni gelişmekte olması işleyiş sorunları yaratmaktadır. Bunun yanında öğretmenler dışındaki akademisyenler, memurlar gibi eğitim çalışanlarının sendikalarda yer almaması ciddi bir sorun teşkil etmektedir. Ayrıca sendikalarda özeleştiri mekanizmasının yeterince işletilememesi, etkili projeler üretilmemesi ve kadınların sendikacılıkta çok yer alamaması önemli sorunlar olarak ifade edilmiştir. Sendika yöneticilerinden bazıları bu yöndeki görüşlerini "Sendikalarla ilgili en büyük sorun, diğer ülkelere kıyasla Türkiye'de sendikacılı̆̆ın yeni olmasıdır (EİY1)."; "Akademisyenler düzeyinde daha fazla katılımols olsa sendikaların daha örgütlü olacağını düşünüyorum (EIY3)." ve "Sendikalar kendi kendilerini yeterince eleştirmiyorlar, eksiklerini görmüyorlar (ESY2)." şeklinde ifade etmişlerdir. Üyeler de buna benzer olarak "Sendikaların kadın kolları yok, bu büyük bir sıkıntı (EBÜ3)."; "Kadınların sendika yönetiminde ön planda olmaması sendikaların erkek egemen yapıya dönüşmesine neden oluyor (EIய̈2)."; "Her sendikanın bir özeleştiri mekanizması olmalı, üyeler kendi sendikalarıyla ilgili eleştirilerde bulunuyorlar ancak bunun dikkate alınmadığını düşünüyorum (ESÜ1)." ve "Ĕgitimin ileriye gitmesi için etkili projeler üretilmeli bunların kağıt üzerinde olmaması gerekir ve bu sendikaların eksikliğinden 
kaynaklanıyor (TESÜ2)." şeklinde görüşler dile getirmiştir.

\section{TARTIŞMA}

Temelde kamu ve özel sektör çalışanlarının ve işverenlerin birbirlerine karşı haklarını korumayı amaçlayan sendikalar, demokratik bir toplum yapısının inşasında önemli bir işlev görmektedir. Sanayileşmiş toplumlarda işçi hareketleriyle ortaya çıkan ve hızla gelişen sendikal faaliyetlerin Türkiye'deki tohumları 20. yüzyılın başlarında Osmanlı döneminde kurulan dernekler ve birliklerle atılmıştır. Cumhuriyetin ilanından sonra dönem dönem yapılan yasal düzenlemelerle çalışanlara sendikal faaliyet hakları tanınmış olmasına rağmen, askeri müdahalelerle pek çok kez bu haklar çalışanlardan geri alınmıştır. Bu nedenle Türkiye'de sendikacılığın kendine pek gelişme ortamı bulamadığı söylenebilir. Eğitim iş kolundaki sendikaların geçmişinin de bu yönüyle çok eskiye dayanmadığı, mevcut sendikaların da ancak 1990'lı yıllarda kurulduğu görülmektedir.

Araştırmada öncelikle sendikaların eğitim konusundaki öncelikleri ele alınmıştır. Sendikaların önceliklerinin başında, eğitimin en temel insan haklarından biri olarak, temel hak ve özgürlükler kapsamında değerlendirilmesi ve bu yönüyle eğitimin parasız bir hizmet olarak sunulması gelmektedir. Bunun yanında sendikalar eğitimde fırsat ve olanak eşitliğinin sağlanması, devletin eğitime bütçeden daha fazla pay ayırarak eğitimin niteliğini artırması ve okulların fiziksel altyapı sorunlarının çözülmesi şeklinde önceliklere sahiptir. Çalışanların hakları yönüyle, sendikaların öncelikleri arasında öğretmenlerin ekonomik koşullarının ve özlük haklarının iyileştirilmesi başta gelmektedir. Eğitim sendikalarının üyeleri temelde öğretmenlerden oluştuğu için öncelikler arasında da öğretmenlerin ilk sırada bulunması doğal bir sonuçtur. Sendikacılık anlayışından hareketle, eğitim sendikalarının en önemli işlevleri, eğitim-öğretim alanının sorunlarına çözüm önerileri getirmesi, demokratik, çağdaş eğitim sistemini içeren bir eğitim anlayışının tesis edilmesi ve öğrenci ve çalışan haklarının elde edilmesi yönünde çalışmalar yapmasıdır. Araştırma bulgularına göre sendikaların öncelikleri bu beklentilerle uyum göstermektedir.

Sendika üyelerinin sendikalardan beklentileri ve sendikalara üye olma gerekçeleri ele alınd1ğında, sendikaların öncelikleriyle üyelerin beklentilerinin büyük ölçüde uyum gösterdiği görülmektedir. Üyelerin sendikalardan beklentileri özellikle iki alanda yoğunlaşmaktadır. Bunlardan birincisi, üyelerin sosyal, demokratik ve ekonomik haklarının savunulmasıdır. Eğitim iş kolu kamu alanındaki en kalabalık kitleyi oluşturduğu için özellikle ekonomik konularda işveren pozisyonundaki hükümetler özlük hakları, ekonomik haklar ve ücretler konusunda cömert davranamamaktadır. Bu yaklaşım, genelde eğitim çalışanlarını, özelde de öğretmenleri ücretler ve ekonomik haklar bakımından diğer kamu çalışanlarına göre dezavantajlı konuma sürüklemiştir. Bu durum sadece Türkiye'ye özgü değil, diğer ülkelerin büyük çoğunluğunda da benzerdir. OECD ülkeleri üzerinde yapılan bir karşılaştırma çalışmasında, ülkelerin büyük çoğunluğunda öğretmen ücretlerinin üniversite mezunu diğer kamu çalışanlarına oranla daha düşük olduğu saptanmıştır (Süngü, 2012). Bu nedenle eğitim işkolunda özellikle mesleki çalışma koşulları, ekonomik haklar, ücretler ve özlük haklarının iyileştirilmesi gibi konularda sistemli sendikal faaliyetlere büyük bir ihtiyaç duyulmaktadır. Türkiye'de yapılan benzer araştırmalar incelendiğinde de üyelerin aynı paralelde beklentilerinin bulunduğu görülmektedir. $\mathrm{Bu}$ araştırmaların bulgularına göre üyeler sendikalardan çalışanların özlük haklarının geliştirilmesine 
katkı sağlanması (Gül, 2007; Taştan, 2013), üyelerin ekonomik hak ve çıkarlarının korunması (Yıldırım, 2007), özlük haklarıyla ilgili hukuk mücadelelerine destek olunması (Baysal, 2010), üyelerin haklarının savunulması ve sorunlarının çözülmesi (Kayıkçı, 2013) yönünde beklentilere sahiptir.

Üyelerin sendikalardan diğer beklentisi ise sendikaların eğitim - öğretim alanındaki sorunların çözümüne katkı sunmalarıdır. Buna göre eğitim sendikalarından eğitim politikalarının şekillenmesinde rol oynaması; eğitimin niteliğinin artırılması, fırsat ve olanak eşitliğinin sağlanması ve öğrenci haklarının korunması yönünde çalışmalar yapması, okulların fiziki olanaklarının geliştirilmesine katkı sağlaması beklenmektedir. Bunların dışında sendikalardan üyelerin sendikacılığa ilişkin bilinçlendirilmesini sağlamaları ve eğitimcilerin ortak sorunlarının çözümünde diğer eğitim sendikalarıyla işbirliği yapmaları beklenmektedir. Kayıkçı (2013) tarafından yapılan araştırmada da üyelerin sendikalardan eğitim sisteminin iyileştirilmesi ve sendikalar arası işbirliği yönünde yüksek beklentilere sahip oldukları görülmüştür. Bu yönüyle bu bulgu da literatürdeki benzer araştırmalarla tutarlıdır.

Türkiye'de eğitim sendikacılığının sorunlarına ilişkin sendika üyelerinin ve yöneticilerinin görüşleri büyük ölçüde benzerlik göstermektedir. En önemli görülen sorun alanları sendikaların siyasetle iç içe olması, çalışanların sendikacılığa karşı olumsuz tutumlar beslemesi, eğitim sendikalarıyla ilgili yapısal sorunlar ve sendikaların işleyişinde karşılaşılan sorunlar şeklinde sıralanmıştır. Eğitim sendikalarının bir siyasi ideolojinin temsilcisi gibi algılanması veya siyasetle ilişkisi hem sendika yöneticileri hem de üyeleri tarafından büyük bir sorun olarak görülmektedir. Literatürde de benzer bulgular görülmektedir. Baysal (2010) ve Yasan'ın (2012) araştırmasında, “sendikaların siyasi görüşlere dayalı olarak bölünmesi"; Yıldırım'ın (2007) araştırmasında "siyasi partilerin sendikalar üzerinde etkisinin olması"; Ulutaş ve Sönmez'in (2011) çalışmasında ise "sendikaların ideolojik temelde yapılanmasının sendikanın idolojik duruşuna neden olması" gibi nedenler eğitim sendiklarının önemli sorunları arasında görülmüştür. Bu durumun en büyük zararı, çalışanların önemli bir kısmının sendikalardan uzaklaşması şeklinde ortaya çıkmaktadır. Çalışanlar, herhangi bir sendikaya üye olduğunda o sendikanın ilişkili olduğu siyasi görüşe göre etiketlenmekten veya baskı görmekten çekindikleri için sendika üyeliğinden uzak durabilmektedir. Mevcut durumda eğitim iş kolunda 1 milyonun üzerindeki çalışanların yaklaşık 340 bininin (\%31) herhangi bir sendikaya üye olmaması (ÇSGB, 2015) bunun bir göstergesi olarak değerlendirilebilir. Sendika üyeliği bulunmayan eğitim çalışanları üzerinde yapılan araştırma bulguları da bu durumu ortaya koymaktadır. Benzer araştırmalarda, çalışanlar sendikaya üye olmama gerekçelerini sendikaların eğitimden çok siyasi görüşlere göre ayrılması (Taştan, 2013), sendikaların siyasi ve ideolojik temelli faaliyetlerde bulunması (Gül 2007; Demir, 2013) şeklinde ifade etmiştir. Bunun yanında katılımcılara göre siyasal iktidara yakın sendikalar daha özgür bir hareket alanına sahip olup gelişirken, muhalif partilerle ilişkilendirilen sendikalar gizli veya açık baskılara maruz kalmaktadır. Bu durum sendikacılığın gelişmesinde önemli bir sorun teşkil etmektedir.

Eğitim çalışanlarının sendikacılığa karşı olumsuz tutum beslemeleri sendikaların önemli sorunlarından bir diğgeridir. Bu olumsuz bakışların temelinde sendika - siyaset ilişkisi, toplumda sendikacılık bilincinin henüz yeterince gelişmemiş olması, sendikacılığa karşı önyargılar veya sendikacılığın önemine inanmama, sendikalara güvenmeme, sendika üyeliğinden dolayı kariyer basamaklarında yükselememe 
endişesi gibi nedenler bulunmaktadır. Eğitim çalışanları arasında örgütlü hareket, sendikal faaliyet ve eylemlere ilgi istenen düzeyde değildir. Çalışanların önemli bir kesimi sendikal faaliyetlerle önemli kazanımlar elde edilebileceğine inanmamakta, sendikaların çalışmalarına güvenmemekte veya sendikalara önyargıyla yaklaşmaktadır. Demir'in (2013) araştırmasında da çalışanların sendikanın yararına inanmadıkları için sendikaya üye olmadıkları saptanmıştır. Çınar'ın (2008:194) araştırmasında ise çal1şanlar sendikaya üye olmanın yönetimce hoş karşılanmayacağı endişesiyle sendikaya üye olmadıklarını belirtmiştir.

Sendikaların önemli bir sorun alanı da yapısal veya mevzuat kaynaklı sorunlar olarak saptanmıştır. Eğitim sendikalarının parçalanmış ve çok sayıda olması, örgütlü gücün bölünmesi ve bu nedenle sendikal gücün zayıflaması olarak yorumlanmakta ve sendikacılık adına önemli bir kayıp olarak görülmektedir. Sendikalar arasında ideolojik ve siyasi temelli bu bölünmüşlük sendikaların eğitimcilerin ortak sorunlarında bile etkin bir güç birliği yapamamasına neden olmakta ve ciddi kazanımlar elde edilememektedir. Benzer araştırma bulgularında da (Tok, 1996; Taştan, 2013) sendikal örgütlerin sayıca fazla olması, sendikalar arasında güçbirliği yapılamaması önemli bir sorun kaynağı olarak saptanmıştır. Bunun yanında yasal olarak eğitim sendikalarının toplu sözleşme hakkına sahip olup grev hakkına sahip olmaması da önemli bir yapısal sorun teşkil etmektedir. Farklı araştırmalarda da (Yıldırım, 2007; Yasan, 2012) sendikaların grev hakkının olmaması önemli sorun alanlarından biri olarak gösterilmiştir.

Benzer araştırmalardan farklı olarak bu araştırmada, işleyişten kaynaklı sorunlar da dile getirilmiştir. Bu kapsamda memur sendikacıl1ğının ve dolayısıyla eğitim sendikalarının Tür- kiye'de henüz yeni olması, öğretmenler dışındaki eğitim çalışanlarının sendikalarda çok fazla temsil edilmemesi, sendikaların güncel sorunlara çözüm üretememesi, sendikalarda özeleştiri mekanizmasının sağlıklı işlememesi ve sendikalarda erkek egemen bir yapının bulunması en önemli sorunlar arasında sayılmiştır.

\section{SONUÇLAR}

Türkiye'de eğitim sendikacılığg henüz istenen düzeye gelememiştir. Eğitim sendikaları eğitim sorunları ile çalışanların haklarının korunması ve artırılması yönünde çalışmalara önem verse de, mevcut sorunlar sendikaların ciddi kazanımlar elde etmelerine engel teşkil etmektedir. Sendika - siyaset ilişkisi, sendikalar arasında ayrışma, sendikalara karşı olumsuz bakış veya önyargılar, yasaların sendikalara yeterince hak tanımamış olması ve işleyişteki aksaklıklar bu sorunların başlıcaları arasında yer almaktadır. $\mathrm{Bu}$ nedenle sendikaların belirli siyasi partilerle ilişkili olduğu algısından kurtulması gerekmektedir. Bunun için sendikaların farklı fikirlerin rahatlıkla dile getirilebildiği, demokratik ortamin sağlıklı bir biçimde işletilebildiği ve güçlü özeleştiri mekanizmalarına sahip bir yapıya dönüşmeleri gerekmektedir. Bunun yanında eğitimcilerin ortak sorunları için gerektiğinde farklı sendikalar arasında işbirliği yapılması ve ortak hareket edilmesi sendikaları daha güçlü ve etkili hale getirecektir. Ayrıca gerekli yasal düzenlemenin bir an önce yapılarak memur sendikalarına grev hakkının tanınması gerekmektedir. Bu sayede sendikal örgütlenmenin çalışanlar için daha cazip hale geleceği ve daha sağlıklı işleyeceği düşünülmektedir. Bu durum ise demokratik toplum yapısının tesisinde önemli bir katkı sunacaktır. 


\section{Kaynakça}

Akyüz, Y. (2007). Doğuşunun yüzüncü yılında Türkiye' de öğretmen örgütlenmesinin ilk on yılına bakışlar (1908 - 1918). Ankara Üniversitesi Osmanlı Tarihi Araştırma ve Uygulama Merkezi Dergisi, 22, 150.

Aldemir, E. (2010). Türkiye'de Memur Sendikalarının Avrupa Birliği Sürecinden Beklentileri: Eğitim Sendikala$r l$ Örneği. Yayımlanmamış Yüksek Lisans Tezi, Ankara Üniversitesi.

Altunya, N. (1998). Türkiye'de Öğretmen Örgütlenmesi(1908-1998), Ankara: Ürün Yayınları.

Ariyawansa, L. (1976). Eğitimin Gelişmesinde ve Cehalete Karşı Verilen Mücadelede Öğretmen Örgütlerinin Görevleri, Dünya Öğretmen Sendikaları Federasyonu Asya Semineri. Colombo, Sri Lanka.

Arlı, G. (2011). Düzenlenebilir Yapılardan Düzenlenmez Formlara Sendikal Hareketin Gelişimi TÖS Eğitim-Sen. Yayımlanmamış Yüksek Lisans Tezi, İstanbul Üniversitesi.

Cerev, G. (2013). Geçmişten Günümüze Öğretmenlerin Sendikal Örgütlenme Mücadelesi, Çankırı Karatekin Üniversitesi Sosyal Bilimler Enstitüsü Dergisi, 4(2), 203- 216.

Çalışma ve Sosyal Güvenlik Bakanlığı. (2015). 2015 Temmuz Kamu Görevlileri Sendikalarının Üye Sayıları https://www.csgb.gov.tr/csgbPortal/csgb.portal?page=sendikauye (21 Ocak 2016'da erişildi).

Çınar, G. (2008). İlköğretim Okullarında Sendikalaşma Faaliyetlerinin Öğretmenler ve Yöneticiler Üzerindeki Etkisi. Yayımlanmamış Yüksek Lisans Tezi, Yeditepe Üniversitesi.

Demir, F. (2013). Öğretmen Görüşlerine Göre Sendikaların Okul Yaşamına Etkileri ve Eğitim Çalışanlarının Sendikalara Üye Olmama Nedenleri, Yayımlanmamış Yüksek Lisans Tezi. Abant İzzet Baysal Üniversitesi.

Demiryürek, E. (2008). Ĕ̆itim İş Kolunda Faaliyet Gösteren Kamu Sendikalarnna Üye Öğretmenlerin Eğitim Sürecinde Kazandırlması Gerekli Gördükleri Değerlere İlişkin Öğretmen Görüşlerinin Değerlendirilmesi. Yayımlanmamış Yüksek Lisans Tezi, Yeditepe Üniversitesi.

Eraslan, L. (2012). Türkiye'de Eğitim Sendikacıllğının Tarihsel Perspektifi ve Günümüz Eğitim Sendikacllığının Değerlendirilmesi, Muğla Üniversitesi Sosyal Bilimler Enstitüsü Dergisi,28, 1-16.

Erdem, A. R. (2013). Köy Enstitüsü Mezunlarının Görüşlerine Göre Köy Enstitüsü Mezunlarının Öğretmen Örgütlenmesine Getirdiği Katkılar, Pamukkale Üniversitesi Sosyal Bilimler Enstitüsü Dergisi, $16,1-7$.

Gemici, Y. (2008). Ĕ̆itimde Sendika Yönetim İlişkileri. Yayımlanmamış Doktora Tezi, Dokuz Eylül Üniversitesi.

Gül, M. H. (2007). Ĕğitim Çalışanlarının Ĕ̆itim Sendikalarına Bakışı, Beklentileri ve Sendikaların Ĕ̆itim Çalışanlarına Yönelik Faaliyetleri ve Beklentileri. Yayımlanmamış Yüksek Lisans Tezi, Yeditepe Üniversitesi.

Gündüz, M. (2010). II. Meşrutiyet ve Erken Cumhuriyet Dönemi, Eğitim ve Öğretim Dernekleri, Turkish Studies- International Periodical For the Languages, Literature and History of Turkish or Turkic, 5(2),1088-1120. 
Işıklı, A. (02-06 Şubat 1977). Dünya Öğretmen Örgütlenmesinin Tarihçesi. Demokratik Eğitim Kurultayı Bildiri Kitabı. Eğitim Sen Yayınları, 75-92.

İren, G. (2009). KKTC'de Öğretmen Sendikalarının Ĕ̆itim Alanına Etkilerinin Öğretmen Ve Sendika Yöneticilerinin Görüşleri Yoluyla Değerlendirilmesi, Yayımlanmamış Yüksek Lisans Tezi, Ankara Üniversitesi.

İşçi ve İşveren Sendikaları ve Sendika Birlikleri Hakkında Kanun (1947). Resmi Gazete, Yayım Tarihi: 26/2/1947. Sayısı: 6542 Numarası: 5018.

Karagöz, M. K. (2010). Küreselleşme Sürecinde Türkiye'deki Sendikacıllk Hareketleri. Yayımlanmamış Yüksek Lisans Tezi, Trakya Üniversitesi.

Kayıkçı, K. (2013). Türkiye'de Kamu ve Eğitim Alanında Sendikalaşma ve Öğretmen ile Okul Yöneticilerinin Sendikalardan Beklentileri. Amme İdaresi Dergisi, 46(1), 99- 126.

Koç, Y. (1998). Sendikacılık Tarihi, Ankara: Türk- İş Eğitim Yayınları, No.1.

Koç, Y. (2012). TÖS Antiemperyalist Bir Öğretmen Örgütü. İstanbul: Kaynak Yayınları.

Koç, Y. (2013). Öğretmen Sendikalarında Yaşanan Sorunlar. Öğretmen Dünyası Dergisi, 400.

Küçükkalay, M. (1997). Endüstri Devrimi Ve Ekonomik Krizlerin Sonucu. Süleyman Demirel Üniversitesi İktisadi ve İdari Bilimler Fakültesi Dergisi, 2.

Mahiroğulları, A. (2001). Türkiye'de Sendikalaşma Evreleri ve Sendikalaşmayı Etkileyen Unsurlar, Cumhuriyet Üniversitesi İktisadi ve İdari Bilimler Dergisi, 2(1), 161- 190.

Mahiroğulları, A. (2011). Dünya'da ve Türkiye'de Sendikacılık, Bursa: Ekin Basım Yayın.

Süngü, H. (2012). Bazı OECD ülkelerindeki öğretmen maaşlarının karşılaştırmalı bir analizi. 21. Yüzyılda Eğitim ve Toplum. 1(2): $21-45$.

Taştan, M. (2013). Eğitim İşkolundaki Sendikalara İlişkin Öğretmen Görüşleri; Nitel Bir Araştırma, Erzincan Üniversitesi Ĕ̆itim Fakültesi Dergisi, 15(1).

TDK. Güncel Türkçe Sözlük. www.tdk.gov.tr (18 Nisan 2015'te erişildi)

Tok, T. N. (1996). Okul Yöneticileri ve Öğretmenlerin Mesleki Örgütlenmeye İlişkin Görüşleri, Kuram ve Uygulamada Ĕ̆itim Yönetim Dergisi, 2(4), 609-629.

Ulutaş, A. ve Sönmez, İ. (2011). Eğitimci Kadınlarn Sendikal Örgütlenme Eğilimleri ve Sendikal Sürece Kattlım Düzeyleri Üzerine Bir İnceleme: (Eskişehir Örneği). TÜBİTAK.

Yasan,T. (2012). İlköğretim Okulu Yöneticilerinin ve Öğretmenlerinin Sendikalara İlişkin Görüşlerinin Farklı Değişkenlere Göre İncelenmesi: Malatya İl Merkezi Örneği. On Dokuz Mayıs Üniversitesi Ĕ̆itim Fakültesi Dergisi 31 (1), 271- 293.

Yıldırım, A. ve Şimşek H 2013. Sosyal Bilimlerde Nitel Arastirma Yontemleri (9. Baskı) Ankara: Seçkin Matbaacilı.

Yıldırım, İ. S. (2007) Türkiye'de Sendikalaşma Sürecinde Öğretmen Sendikaları ve Siyasetle İlişkisi: Adapazarı Örneği. Yayımlanmamış Yüksek Lisans Tezi, Sakarya Üniversitesi. 


\section{Extended Summary}

Unionization in the world came into being as a result of industrialization and establishment of factories. With the emergence of the working class, unions were needed to protect workers' rights and interests against employers and governments. Unions offer services to their members such as representing them in their workplaces, providing them with training and professional development opportunities, protecting their social, economic and personal rights, offering legal aid when needed and promoting cooperation among members.

The ground of unions in Turkey was laid by some associations and institutions established in the Ottoman era in early $20^{\text {th }}$ century. Following the declaration of the Republic in Turkey, through some legal regulations, individuals were granted the right to be involved in union activities; yet, during the periods of military coups, these rights were often taken away from workers. Therefore, it can be argued that unionism could not find suitable environments to thrive in Turkey. Thus, the history of the unions operating in the field of education in Turkey is relatively new and most of the existing unions were established only in 1990s. The four education unions having the highest numbers of members in Turkey can be presented in rank order as follows: Eğitim-Bir-Sen, Türk Eğitim-Sen, Eğitim-Sen and Eğitim-İş established in 2005.

The purpose of the current study is to determine the primary goals of the education unions operating in Turkey, their members' expectations from them and their reasons for being a member and their problems on the basis of the opinions of union managers, member teachers and school directors. The originality of the current study stems from the simultaneous elicitation of the opinions of union managers, teachers and school directors and revelation of the primary goals of the unions, their members' expectations and their problems within the same study.

Within the context of the current study employing a qualitative research design, the data were collected by using semi-structured interview technique in a face-to-face application. Within the study group of the current research, totally 12 union members and 12 union managers of the four unions having the highest numbers of members were included (Eğitim-Bir-Sen, Türk Eğitim-Sen, Eğitim-Sen, Eğitim-İş). The study group was constructed by using the purposive sampling and maximum diversity methods. For different opinions and perceptions to be reflected in the research findings, selection of the participants who are members of a union was made as follows: teachers $(\mathrm{N}=4)$, vice school directors $(\mathrm{N}=4)$ and school directors $(\mathrm{N}=4)$ and selection of the participants who have some administrative duties in a union was made as follows: branch chairpersons $(\mathrm{N}=4)$, district presidents $(\mathrm{N}=3)$, vice district presidents $(\mathrm{N}=2)$ and secretaries $(\mathrm{N}=3)$. The collected data of the present study were analyzed through the content analysis technique. In the analysis of the data, a code was assigned to each participant. The participants' opinions were first conceptualized, then common themes were constructed and the opinions were presented and interpreted within the frameworks of these themes.

The findings of the study revealed that the main priorities of the unions are consideration of education within the context of the basic rights and freedoms as one of the basic human rights and in this regard, provision of education as a service free of charge. In addition to these, the unions attach great importance to the establishment of equality in education, to the improvement of the quality of education by allocating a larger share from the budget and finding solutions to schools' problems related to physical infrastructure conditions. With regards to the rights of workers, the main priorities of the unions are 
the improvement of the economic conditions and personal benefits of workers. It was found that the unions' priorities and the members' expectations from their unions are in compliance to a great extent. The members' expectations from their unions are concentrated in two areas. First one is their defending their members' social, democratic and economic rights and the other one is their contributing to the solution of the problems in the field of education and instruction. The union members' opinions and the managers' opinions about the problems of the unionization in education match to a large extent. The most important problems are viewed to be political affiliations of the unions, education workers' negative attitudes towards unionization, lack of right to go on a strike and some other structural and operational problems.

In conclusion, the development of unionization in the field of education is not at the desired level in Turkey. Though they attach great importance to educational problems and protection and promotion of workers' rights, the existing problems stand as serious obstacles in front of them to achieve their goals. Therefore, first the perception that the unions are affiliated to political parties should be abolished. To do so, the unions should be converted to organizations in which different opinions can be expressed freely, democratic conditions are established well and sound mechanisms of self-criticism are present. In addition, establishing cooperation between unions when necessary to find solutions to the common problems of educators will make the unions stronger and more efficient. Moreover, the right to go on a strike should be granted to the unions by passing laws necessary for this. Thus, organization in unions can be rendered more attractive for workers and they can function better in the future. This is believed to make an important contribution to the establishment of a democratic social structure. 